\title{
EFEKTIFITAS METODE PEMBELAJARAN KITAB KUNING DI MADRASAH DINIYAH PONDOK PESANTREN AL-MAHALLI BRAJAN WONOKROMO PLERET BANTUL TAHUN AJARAN 2013/2014
}

\author{
Azuma Fela Sufa \\ PAI STIA Alma Ata Yogyakarta
}

\begin{abstract}
Abstrak
Azuma Fela Sufa, Efektifitas Metode Pembelajaran Kitab Kuning di Madrasah Diniyah Pondok Pesantren Al-Mahalli Brajan Wonokromo Pleret Bantul tabun ajaran 2013/2014. Program Studi Pendidikan Agama Islam Sekolab Tinggi Ilmu Agama Alma Ata Yogyakarta 2014.

Latar belakang penelitian ini, metode-metode yang digunakan pada umumnya belum sepenubnya membantu santri dalam memahami kitab kuning. Oleb karena itu, para ustadz pondok pesantren berusaba menggali kreatifitas mereka untuk mencari metode-metode lain yang bisa menunjang pembelajaran kitab kuning di pondok pesantren Al-Mahalli. Sehingga para santri akan lebib mudah dalam belajar menggunakan kitab kuning dan mereka merasa senang belajar kitab kuning. Dengan demikian, peneliti ingin mengetahui metode apa saja yang digunakan oleb ustadz untuk proses belajar mengajar mereka, efektif atau tidak setelah menggunakan metode-metode tersebut serta faktor penghambat dan faktor pendukung dalam pembelajaran kitab kuning tersebut.

Penelitian ini termasuk jenis kualitatif naturalistik. Adapun subyek penelitiannya adalah pengasub, ustadz/ustadzah dan para santri kelas Wustho pondok pesantren Al-Mahalli. Metode pengumpulan data menggunakan Observasi, wawancara dan dokumentasi. Teknik analisis data menggunakan sebelum di lapangan dan selama di lapangan model Miles and Huberman.

Hasil yang diperoleh dari penelitian ini adalah, metode yang digunakan dalam pembelajaran kitab kuning sudah efektif dan berjalan dengan baik. Dilibat dari basil observasi mereka sangat bersemangat dalam belajar kitab kuning dan akan berpengaruh pada pemahaman mereka. Kemudian selain dari hasil observasi dan wawancara, peneliti mengambil data berupa nilai dan jika dilihat dari rata-rata nilainya yang bagus, maka metode yang digunakan sudab efektif dan baik.

Faktor penghambat dalam pembelajaran diantaranya, Masalab waktu, mayoritas santri belum mengenal kitab kuning, dalam metode sorogan, sering kali terlibat beberapa santri tidak fokus, dalam mengkbatamkan kitab memerlukan waktu yang lama. Faktor pendukung, adanya ustadz/ustadzab
\end{abstract}


yang berpengalaman sesuai dengan bidangnya masing-masing, tersedianya sarana dan prasarana yang cukup memadai, peserta didik mayoritas tinggal di Pondok Pesantren sehingga secara otomatis terkondusif oleh lingkungannya tersebut.

Upaya yang dilakukan oleb para ustadz pondok pesantren diantaranya adalah, selain pada sore hari madrasah diniyah dilakukan pada malam hari sebingga pembelajaran kitab kuning bisa optiimal. Serta para ustadz selalu berusaha menggali kreatifitas mereka supaya etode-metode yang digunakan dalam pembelajaran kitab kuning bisa berjalan dengan baik dan efektif.

\begin{abstract}
Azuma Fela Sufa, Effective Learning Method Yellow Book in Madrasab Diniyah Pondok Pesantren Al-Mahalli Brajan Wonokromo Pleret Bantul academicyear 2013/2014. Islamic Religious Education Program School of Religion Yogyakarta Alma Ata, 2014.

The background of this research, the methods used are generally not fully assist students in understanding the yellow book. Therefore, the boarding school chaplain tried to explore their creativity to find other methods that can support learning in the yellow book pesantren Al-Mahalli. So that the students will be easier to learn to use the yellow book and they were delighted to learn of the yellow book. Thus, researchers want to know what the method used by the cleric for their teaching and learning processes, effective or not after using these methods as well as factors inhibiting and supporting factors in learning the yellow book.

This research includes qualitative naturalistic. The subjects of the study are caregivers, chaplain/cleric and the students Wustho class boarding school al-Mahalli. Methods of data collection using observation, interviezes and documentation. Data analysis techniques used in the field before and during field model of Miles and Huberman.
\end{abstract}

The results obtained from this study is that the methods used in the yellow book learning is effective and runs well. Judging from the results of their observations are very enthusiastic about learning the yellow book and will affect their understanding. Then apart from observations and interviewes, the researchers took the data as a value and when viewed from the average value is good, then the method used was effective and well.

Such inbibiting factors in learning, problem of time, the majority of students are not familiar yellow book, the method sorogan, often seen some students do not focus, in mengkhatamkan book takes a long time. Supporting factors, the chaplain/ cleric experienced in accordance with their respective fields, the availability of 
facilities and infrastructure are adequate, the majority of students live in boarding school so that automatically terkondusif by the environment.

Efforts made by the boarding school chaplain include, in addition to the afternoon of madrasab diniyab done at night so that learning can be optiimal yellow book. As well as the cleric always tried to explore their creativity in order etode-learning methods used in the yellow book can be run properly and effectively.

\section{PENDAHULUAN}

Bahasa Arab merupakan salah satu bahasa mayor di dunia yang dituturkan oleh lebih dari 200.000.000 umat manusia. Bahasa ini digunakan secara resmi oleh kurang lebih 20 negara. Dan karena ia merupakan bahasa kitab suci dan tuntunan agama umat sedunia, maka tentu saja ia merupakan bahasa yang paling besar signifikannya bagi ratusan juta muslim sedunia, baik yang berkebangsaan Arab atau bukan. ${ }^{1}$

Oleh karena itu mempelajari bahasa arab amat penting bagi kita umat Islam, karena ucapan dalam kita sholat dengan menggunakan bahasa arab dan kitab suci Al-Qur'an juga menggunakan bahasa arab, begitu pula kebanyakan buku-buku agama Islam ditulis dengan bahasa arab. Oleh karena itu, di negeri-negeri Islam diutamakan sekali mempelajari bahasa arab, bukan saja di pesantren-pesantren tetapi juga di sekolah-sekolah.

Namun dalam rangka mengkaji makna yang terkandung dalam Al-Qur'an dan $\mathrm{Al}-\mathrm{Hadis}$ maupun buku-buku Islam yang ditulis dengan menggunakan bahasa arab terutama yang arab gundul atau sering disebut dengan istilah kitab kuning bukanlah suatu hal yang mudah, karena sebelum melakukannya kita dituntut mampu membaca secara harfiah serta mengerti artinya, padahal kita tidak bisa membaca dan mengartikannya tanpa mengetahui dulu ilmu alat. Oleh karena itu, bukan hal yang mudah bagi seorang guru bahasa arab menyampaikan materinya. Dia dituntut untuk bisa menggunakan cara yang paling efektif dan efisien agar siswa benar-benar paham dan mengerti serta mampu mengaplikasikannya.

Tujuan pengajaran bahasa asing termasuk bahasa arab di Indonesia sebenarnya adalah agar siswa mampu menggunakan bahasa asing (Arab) secara aktif maupun pasif. ${ }^{2}$ Untuk mencapai tujuan tersebut siswa diharapkan memperoleh 4 ketrampilan berbahasa yaitu : ketrampilan mendengar, membaca, berbicara dan menulis. $^{3}$

${ }^{1}$ Azhar Arsyad, Bahasa Arab dan Metode Pengajarannya, (Yogyakarta,: Pustaka Pelajar, 2003) hlm 1

${ }^{2}$ Umar Asasudin Sokah,Dip TEFL, Problematika Pengajaran Bahasa Arab dan Inggris, (Yogyakarta: Nur Cahaya, 1982) hlm 33

${ }^{3} \mathrm{Ibid}, \mathrm{hlm} 61$

LITERASI, Volume V, No. 2 Desember 2014 
Keempat hal di atas merupakan sesuatu yang ideal. Namun pada kenyataannya, banyak lembaga pendidikan di Indonesia hanya mengacu pada kemampuan berbahasa secara pasif. Hal ini terjadi tidak hanya pada lembagalembaga pendidikan Islam swasta, namun juga pada sekolah-sekolah negeri yang juga berada di bawah naungan Departemen Agama. Bahkan pengajaran berbahasa arab secara pasif pun pada kenyataannya masih perlu banyak peningkatan. Oleh karena itu, bisa dikatakan tujuan pengajaran bahasa arab sebagaimana yang tersebut di atas tidak sepenuhnya tercapai. Kenyataan itu pun terjadi di Madrsah Diniyah AlMahali yang sekarang sedang mempelajari bahasa arab terutama pada kitab kuning.

Madrasah Diniyah Al-Mahali sebagai lembaga pendidikan formal tidak sepenuhnya mengikuti kurikulum Depag. Dalam hal ini kurikulum yang digunakan merupakan perpaduan kurikulum Depag dengan kurikulum lokal (pesantren).

Sebenarnya persoalan yang tidak dapat diabaikan peranannya dalam mencapai tujuan tersebut adalah aspek metodologis dlam pengajaran kitab kuning. Secara umum kitab kuning adalah pegangan pokok pondok-pondok pesantren. Oleh karena itu, sudah otomatis metode yang dipakai dalam pengajarannya adalah metode pengajaran ala pondok-pondok pesantren pada umumnya. Metode pengajaran kitab kuning di pondok-pondok pesantren satu sama lain sebenarnya tidak banyak berbeda. Metode tersebut bisa dikatakan sudah berumur ratusan tahun sebagaimana usia sejarah pesantren itu sendiri. Bersamaan dengan berlalunya waktu, pengajaran dengan metode alapesantren mulai menuai banyak kritik. Kritikan ini terutama disuarakan oleh para pakar pendidikan modern. Banyak pendapat mengenai metode pengajaran ala pesantren ini. Satu pihaak memandangnya sebagai suatu kekolotan dan tidak teratur. ${ }^{4}$ Tapi dipihak lain mengatakan metode yang dipakai oleh pondokpondok pesantren cukup efektif. ${ }^{5}$

Dengan adanya aneka ragam pandangan para pakar, baik pakar dari luar pesantren maupun dari dalam pesantren sendiri, dan adanya kesadaran akan pentingnya metode pengajaran di dalam mencapai tujuan pengajaran, serta penulis ingin mengetahui apakah metode-metode yang digunakan para ustadz di Pondok Pesantren Al-Mahalli ini bisa dikatakan efektif atau belum, maka peneliti ingin meneliti tentang pengajaran kitab kuning di Madrasah Diniyah Al-Mahali Brajan Wonokromo Pleret Bantul. Khususnya tentang Efektifitas Metode Pembelajaran Kitab Kuning di Madrasah Diniyah Pondok Pesantren Al Mahalli Barajan Wonokrono Pleret Bantul.

${ }^{4}$ Deliar Noer, Gerakan Modern Islam di Indonesia, (Jakarta: LP3S, 1985), hlm 15

${ }^{5}$ Zamakhsyari Dhofier, Tradisi Pesantren, (Jakarta: LP3ES), hlm 29 
Berdasarkan latar belakang masalah di atas dapat disusun tiga rumusan masalah utama dalam penelitian ini yaitu: pertama, untuk mengetahui apa saja metode yang digunakan dalam pembelajaran kitab kuning di Pondok Pesantren Al-Mahalli? Kedua sejauh mana efektifitas metode yang digunakan dalam pembelajaran kitab kuning santri Al-Mahalli? Dan ketiga apakah faktor penghambat dan faktor pendukung dalam pembelajaran kitab kuning?

Dari rumusan masalah tersebut, penelitian ini bertujuan untuk Untuk mengetahui apa saja metode yang digunakan dalam pembelajaran kitab kuning. Untuk mengetahui efektifitas penggunaan metode pembelajaran kitab kuning di Pondok Pesantren Al-Mahalli. Dan untuk mengetahui faktor penghambat dan faktor pendukung dalam pembelajaran kitab kuning.

\section{HASIL PENELITIAN DAN PEMBAHASAN Hasil Penelitian}

\section{Implementasi Metode Bandongan dan Metode Sorogan dalam Pembelajaran Kitab Kuning di Kelas Wustho Pondok Pesantren Al-Mahalli}

Kitab kuning yang dikaji di Pondok Pesantren Al-Mahalli meliputi hadist, Fiqh, Tafsir, Tajwid, Nahwu, Akhlak dan lain-lain. Adapun tujuan pembelajaran kitab kuning di Pondok Pesantren Al-Mahalli supaya santri bisa memahami arti dan makna dari kitab kuning tersebut dan bisa mengamalkannnya dalam kehidupan sehari-hari.

Macam-macam kitab yang di pelajari di kelas Wustho Pondok Pesantren Al-Mahalli pada tahun ajaran 2013/2014 adalah sebagai berikut: ${ }^{6}$ Mukhtarul Hadis, Maqsud, Tanqihul Qaul jilid 2, Bidayatul Bidayah, Imrity, Ta'limul Muta'alim, Fatkhul Qarib dan Taqrib.

Metode yang sering digunakan di Madrasah Diniyah pondok pesantren Al-Mahalli ini adalah metode sorogan dan bandongan, tetapi ustadz-ustadz yang menggunakan metode lain, seperti metode diskusi, ceramah, kuiz dan lain-lain.

Kebanyakan latar belakang santri tidak berasal dari pondok pesantren, dan kebanyakan dari mereka belum menganal kitab kuning, maka para ustadz dan ustadzah di Pondok Pesantren Al-Mahalli harus mampu memilih metode yang sesuai supaya penyampaian pembelajaran kitab kuning dapat tersampaikan dengan mudah kepada para santri.

${ }^{6}$ Dokumentasi berupa daftar mata pelajaran Pondok Pesantren Al-Mahalli, dikutip pada tanggal 15 April 2014 


\section{Pembelajaran Kitab Kuning dengan Metode Bandongan di Kelas Wustho}

Kegiatan awal dimulai ustadz/ustadzah masuk ke dalam kelas dengan persiapan yang cukup lengkap dan penampilan rapi. Ustadz mengucapkan salam kepada semua santri dan santri menjawab salam dari ustadz. Sebelum pelajaran dimulai, ustadz memimpin do'a terlebih dahulu dan mengabsen semua santri.

Kemudian kegiatan selanjutnya yaitu kegiatan inti atau proses belajar mengajar. Salah satu kitab yang dikaji dengan menggunakan metode bandongan di kelas Wustho Pondok Pesantren Al-Mahalli adalah kitab Ta'limul Muta'alim.

Pembelajaran dengan metode bandongan di sini yaitu ustadz membacakan kitab dan diterjemahkan ke dalam bahasa jawa atau sering disebut dengan membacakan makna gandulnya kemudian diterangkan dengan menggunakan bahasa Indonesia.

Ketika proses belajar mengajar dimulai, suasana kelas hening tidak terdengar suara apapun kecuali suara ustadz yang sedang membacakan kitabnya. Tugas para santri yaitu mendengarkan ustadz yang sedang membacakan kitabnya dan menuliskan makna gandul dari bacaan yang ustadz bacakan. Para santri selain menuliskan arab pegon atau maknanya dalam kitabnya masing-masing, mereka juga menuliskan keterangan dari kitab tersebut dengan bahasa Indonesia. ${ }^{8}$

Dalam menggunakan metode bandongan ustadz tidak akan mengetahui mana santri yang sudah paham atau belum, karena mereka hanya mendengarkan bacaan ustadznya. Oleh karena itu, ustadz di Pondok Pesantren Al-Mahalli akan membacakan kitabnya, ustadz akan sedikit menjelaskan isi kandungan dari materi yang sedang dipelajari. Selain itu, ustadz selalu menanyakan kepada santrinya mana yang belum paham. Dan untuk menambah keyakinan ustadz tentang pemahaman santri, ustadz terkadang memberi beberapa pertanyaan tentang materi yang sudah dipelajari para santri.

Dan kegiatan yang terakhir yaitu kegiatan penutup. Setelah ustadz selesai menyampaikan materi dan menjawab pertanyaan-pertanyaan dari santri (jika ada pertanyaan), maka ustadz akan menyimpulkan kembali materi yang telah disampaikan. Dari hasil pengamatan di dalam kelas banyak santri yang aktif. Selama penulis melakukan beberapa kali observasi dalam metode bandongan, tercatat kebanyakan santri aktif dalam mengajukan pertanyaan, karena pelajaran Fiqh sangat penting dalam kehidupan mereka untuk melakukan ibadah dan sering mereka temui masalah yang mereka belum mengetahui cara mengatasinya

2014

${ }^{7}$ Observasi proses pembeajaran di Pondok Pesantren Al-Mahalli pada tanggal 14 April

${ }^{8}$ Observasi pembelajaran Kitab Ta'limul Muta'alim di Wustho Pondok Pesantren AlMahalli pada tanggal 14 April 2014 
atau hukum-hukumnya. Setelah itu, ustadz akan mengakhiri pembelajaran dengan do'a bersama dan salam.

\section{Pembelajaran Kitab Kuning dengan Metode Sorogan di Kelas Wustho}

Kitab kuning yang diajarkan dengan menggunakan metode sorogan di kelas Wustho Pondok Pesantren Al-Mahalli adalah kitab Taqrib, adapun metode sorogan adalah metode pengajaran yang bersifat individual yang dilaksanakan dengan cara santri satu persatu mengahadap ke ustadz untuk menyetorkan atau membacakan kitabnya, kemudian santri disuruh menerjemahkan dan menerangkan isi kandungan dalam materi tersebut secara bergiliran.

Adapun tujuan pembelajaran kitab kuning dengan menggunakan metode sorogan yaitu : Pertama, supaya santri lancar dalam membaca bahasa arab. Kedua, supaya santri paham makna dari kitab kuning. Ketiga, supaya santri paham dengan nahwu shorofnya. ${ }^{?}$

Proses pembelajaran kitab kuning tidak jauh berbeda dengan proses pembelajaran dengan metode bandongan. Kegiatan awal ustadz masuk ke dalam kelas dengan persiapannya. Ustadz memberi salam dan santri menjawabnya, kemudian ustadz memimpin do'a dan mengabsennya.

Kegiatan inti, karena menggunakan metode sorogan maka ustadz langsung memanggil salah satu santri untuk membacakan kitabnya dihadapan ustadz. Santri yang mendapat panggilan akan langsung membacakan makna gandul dan menjelaskan apa yang telah dibacakan tadi ke dalam bahasa Indonesia. Sementara ustadz mendengarkan sambil memberi catatan, komentar atau bimbingan apabila diperlukan. Sedangkan santri yang lain menyimak dan mendengarkan dengan seksama, karena kitab yang dikaji santri semuanya sama. Jika santri dalam menyetorkan terjadi kesalahan ustadz akan memberi kesempatan kepada santri untuk membenarkannya dahulu sebelum ustadz membenarkan kesalahan tersebut. Karena apabila ustadz langsung membenarkan maka santri akan malas untuk belajar terlebih dahulu dan akan menyepelekan ustadznya.

Dalam metode sorogan biasanya santri hanya disuruh menyetorkan dihadapan ustadznya, akan tetapi di pondok pesantren Al-Mahalli metode sorogan akan ditambah dengan ustadz memberi kesempatan kepada santri yang lain untuk bertanya kepada santri yang telah selesai setor kepada ustadznya. Pertanyaan yang boleh diajukan sesuai dengan materi yang dibacakan santri tadi, dan santri tersebut akan menjawab sesuai dengan kemampuannya. Metode tersebut akan seperti diskusi, ada yang bertanya dan ada yang menanggapinya.

${ }^{9}$ Wawancara dengan Ustadz Imam Fauzi pengampu kitab Nahwu Shorof, pada tanggal 15 April 2014

LITERASI, Volume V, No. 2 Desember 2014 
Setelah selesai ustadz juga akan menanggapi pertanyaan dari santrinya. Dalam sekali pertemuan, pembelajaran kitab kuning dengan menggunakan metode sorogan ini hanya ada 2 atau 3 santri yang bertugas menyetor bacaan kitabnya, itu bertujuan agar waktu pembelajaran kitab kuning dengan metode sorogan akan lebih efektif. ${ }^{10}$

Dalam pembelajaran kitab Taqrib diharuskan semua santri kelas Wustho memiliki kitab tersebut sebagai pegangan bagi santri.

\section{Pembahasan}

Penelitian ini bertujuan untuk mengetahui bagaimana dan apa saja metode yang digunakan dalam pembelajaran kitab kuning dan sejauh mana keefektifan dalam menggunakan metode tersebut dalam pembelajaran kitab kuning di Pondok Pesantren Al-Mahalli. Setelah melakukan penelitian dari hasil wawancara dan observasi, akhirnya peneliti memperoleh deskripsi kualitatif mengenai efektifitas metode pembelajaran kitab kuning di Pondok Pesantren Al-Mahalli Brajan Wonokromo Pleret Bantul, yaitu:

Prtama, metode pembelajaran kitab kuning di Pondok Pesantren AlMahalli menggunakan metode Bandongan, Sorogan dan Wetonan. Pada umumnya metode bandongan adalah di mana dalam penyampaian kitab kuning santri mendengarkan sedangkan ustadznya menyampaikan materi dan menjelaskannya. Pernyataan tersebut terdapat dalam bukunya Zamakhsyari Dhofier yang berjudul "Tradisi Pesantren". Beberapa kitab yang dikaji di Pondok Pesantren Al-Mahalli khusunya kelas Wustho, juga menggunakan metode tersebut, selain ustadz membacakan kitab dan menerjemahkannya ke dalam bahasa jawa kemudian menjelaskannya, ustadz juga menggunakan metode-metode lain agar para santri lebih mudah memahami dan tidak merasa jenuh dalam proses belajarnya. Metode yang sering dilakukan yaitu ustadz membuat beberapa kelompok dan masingmasing kelompok ditunjuk 1 santri untuk memimpin kelompoknya. Setelah itu, ustadz akan memberi tugas kepada masing-masing kelompok untuk mendiskusikan tentang materi yang sudah dipelajari kemudian mempresentasikan di depan kelas. Dalam presentasi juga akan dibuka sesi tanya jawab.

Selain metode bandongan, di Pondok Pesantren Al-Mahalli juga menggunakan metode sorogan. Di dalam bukunya Zamakhsyari Dhofier yang berjudul "Tradisi Pesantren" metode sorogan maksudnya para santri diberi materi oleh ustadz, kemudian setelah santri mempelajarinya mereka menyetor dihadapan ustadz. Metode yang digunakan di Pondok Pesantren juga tidak jauh

${ }^{10}$ Observasi pembelajaran kitab kuning Taqrib di kelas Wustho Pondok Pesantren AlMahalli, pada tanggal 14 April 2014 
berbeda, hanya ada penambahan metode di akhir pelajaran setelah para santri menyetorkan bacaannya. Di sini santri yang bertugas menyetorkan bacaan kitabnya, kemudian ustadz memberi kesempatan pada santri lain yang tidak mendapat tugas menyetor bacaannya untuk bertanya. Metode ini akan menjadi seperti forum diskusi, ada santri yang bertanya, kemudian dijawab oleh santri yang bertugas tadi, kemudian ada juga santri lainnya yang menyanggah jawaban atau menambahi jawaban tersebut. Metode tersebut adalah salah satu metode yang sering digunakan untuk melengkapi metode sorogan dalam pembelajaran kitab kuning. Dan mereka berpendapat dengan metode-metode tersebut sangat membantu mereka dalam mengikuti proses belajar. Selain itu, santri yang tidak mendapat tugas untuk maju juga tidak akan merasa bosan dan menganggur, karena mereka juga diharuskan untuk menyimaknya.

Adapun materi yang terdapat dalam kitab Taqrib (kitab yang digunakan untuk sorogan) adalah sebagai berikut:

Tabel 3. Materi Kitab Taqrib ${ }^{11}$

\begin{tabular}{|c|c|c|c|}
\hline No & Materi & No & Materi \\
\hline 1 & مقد مه & 6 & احكام الحج \\
\hline 2 & احكام الطهارة & 7 & احكام البيو ع و غير ها من المعا ملات \\
\hline 3 & احكام الصلاة & 8 & احكام الفر اءض و الوصايا \\
\hline 4 & احكام الزكاة & 9 & احكام النكاح و ما بتعلق به \\
\hline 5 & بيان احكام الصيام & & \\
\hline
\end{tabular}

\section{Efektifitas metode pembelajaran kitab kuning}

Hasil dari wawancara, observasi dan dokumentasi metode-metode yang digunakan para ustadz untuk menunjang dalam pembelajaran kitab kuning sudah baik dan bisa dikatan efektif, seperti kriteria yang ada dalam buku Muh. User Usman yang berjudul "Menjadi Guru Profesional". Dalam pembelajaran dapat dikatakan efektif apabila: ${ }^{12}$

Dari segi pendidik.

\section{Prinsip individualitas}

Pembelajaran akan berjalan efektif apabila ustadz selalu memperhatikan karakteristik dari masing-masing peserta didiknya, karena santri akan merasa

${ }^{11}$ Dokumentasi berupa daftar materi kitab Taqrib dikutip dari kitabnya, pada tanggal 15 April 2014

${ }^{12}$ Muh.User Usman, Menjadi Guru Profesional, (Bandung: PT, Remaja Rosda Karya, 1995), hlm 16. 
mendapat perhatian dan mereka akan semakin bersemangat sehingga proses pembelajaran akan maksimal.

\section{Peragaan pembelajaran}

Belajar yang efektif harus dimulai dengan pengalaman langsung atau pengalaman kongkrit menuju ke pengalaman yang abstrak. Apabila dalam proses pembelajaran pendidik menggunakan media praktik maka akan memudahkan santri dalam memahami materi tersebut.

Dari segi peserta didik

a. Dapat melibatkan peserta didik secara aktif

b. Dapat menarik minat peserta didik

c. Dapat membangkitkan motivasi peserta didik

Dari hasil wawancara kepada salah satu santri, mereka merasakan peningkatan pemahaman tentang kitab kuning, seperti cara membaca, cara memaknai dan cara memahami isi kandungan yang ada dalam kitab tersebut. ${ }^{13}$

Hasil Belajar Dari Pembelajaran Kitab Kuning Dengan Metode Bandongan Dan Metode Sorogan

\section{Hasil Belajar Dari Pembelajaran Kitab Kuning Dengan Metode Bandongan}

Bentuk evaluasi dari pembelajaran kitab kuning dengan metode bandongan yang diterapkan oleh ustadz pada kelas Wustho ada dua macam, pertama, evaluasi setiap satu semester yaitu setiap selesai satu semester pondok pesantren Al-Mahalli mengadakan ujian/imtihan berupa tes tertulis, yang harus diikuti oleh semua santri dan dilakukan pada waktu yang telah ditentukan oleh dewan pendidikan pondok pesantren Al-Mahalli. Yang bertujuan untuk mengetahui kemampuan siswa dalam memahami kitab kuning yang telah dipelajarinya selama satu semester. Kedua, penilaian kitab, yaitu penilaian kitab santri setelah mengkhatamkan satu jilid kitab. Ustadz akan menilai seluruh kitab santrinya, yang dinilai yaitu penulisan terjemahan atau penulisan arab pegonnya, sesuai tidak dengan kaidah hukum nahwu shorofnya. Sehingga saat proses pembelajaran santri diharapkan termotivasi untuk selalu mendengarkan keterangan dari ustadz dan menuliskannya di kitab masing-masing. ${ }^{14}$

\footnotetext{
${ }^{13}$ Intani Fathima, santriwati Al-Mahalli kelas Wustho, wawancara pada tanggal 15 April 2014

${ }^{14}$ Hasil wawancara dengan ustadz Imam Fauzi pengampu kitab Nahwu Shorof, pada tanggal 15 April 2014
} 
Untuk mengetahui hasil belajar santri dengan menggunakan metode bandongan dalam pembelajaran kitab kuning, maka penulis mengumpulkan nilai semester awal. Sebagaimana yang tertera pada tebel di bawah ini.

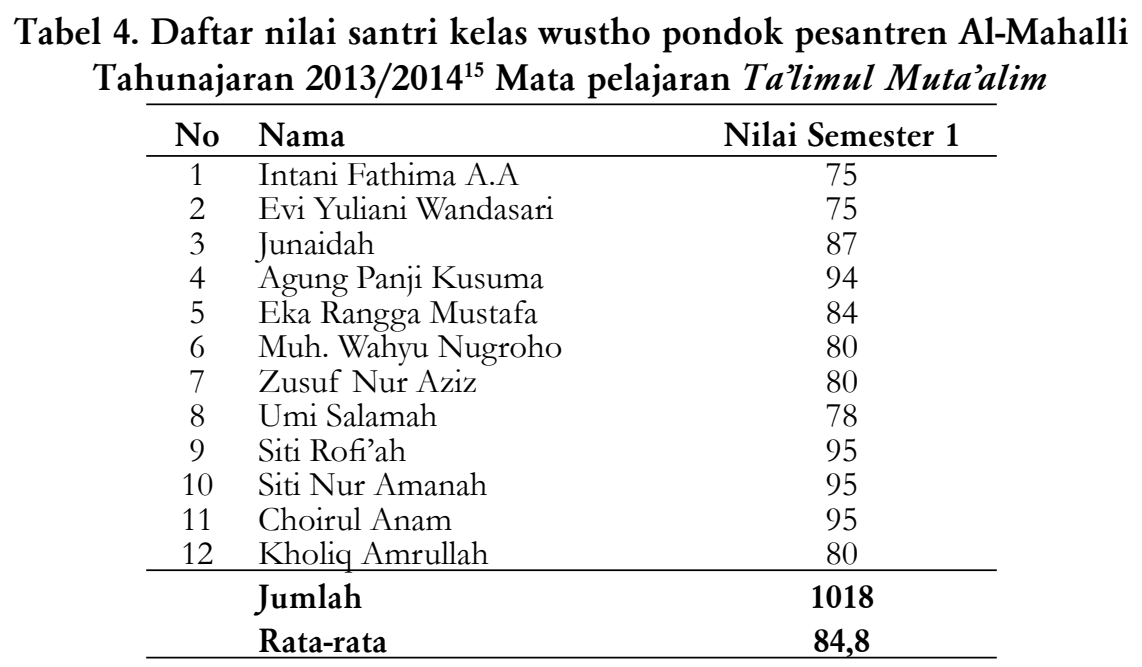

Dilihat dari perolehan nilai belajar pada tebel di atas, santri kelas Wustho bisa dikatakan sangat baik karena nilai rata-rata mereka sangat baik, menurut Kemp dalam Mudhlofir di bukunya "teknologi intruksional" mengatakan bahwa ukuran efektif dapat diukur dari berapa jumlah santri yang berhasil mencapai tujuan belajar dalam waktu yang telah di tentukan. ${ }^{16}$ Dan pembelajaran kitab kuning tersebut termasuk dalam pembelajaran yang efektif karena telah memenuhi ketentuan yang ada pada bukunya Muh. User Usman yang berjudul "Menjadi Guru Profesuional" yang mengatakan bahwa dalam suatu pembelajaran dapat dikatakan efektif apabila dari segi pendidik dan dari segi peserta didik telah tercapai.

Di dalam buku Suharsimi Arikunto juga menyebutkan kriteria yang sering digunakan dalam penilaian, yaitu:
a. $80-100$ : sangat baik
b. $66-79$ : baik
c. $56-65$ : cukup baik
d. $40-55$ : kurang $^{17}$

${ }^{15}$ Dokumentasi berupa daftar nilai mata pelajaran Ta'limul Muta'alim , pada tanggal 15 April 2014

${ }^{16}$ Mudhlofir, Teknologi Instruksional, (Bandung: Remaja Rosda Karya, 1990), hlm 145146.

${ }^{17}$ Suharsimi Arikunto, Dasar-dasar Evaluasi Pendidikan, (Jakarta: Bina Aksara, 1995), 


\section{Hasil Belajar Dari Pembelajaran Kitab Kuning Dengan Metode Sorogan}

Untuk mengetahui hasil belajar santri dengan menggunakan metode sorogan dalam pembelajaran kitab kuning, maka penulis telah mengumpulkan nilai semester satu mata pelajaran Taqrib.

Begitu juga dengan bentuk evaluasi dari pembelajaran kitab kuning dengan metode sorogan yang diterapkan oleh ustadz pada kelas Wustho ada dua macam yaitu, pertama, evaluasi setiap satu semester yaitu setiap selesai satu semester pondok pesantren Al-Mahalli mengadakan ujian/imtihan berupa tes tertulis yang diikuti seluruh santri terutama Wustho dan dilakukan pada waktu yang telah ditentukan oleh dewan pendidikan pondok pesantren Al-Mahalli yang bertujuan untuk mengetahui kemampuan siswa dalam memahami kitab kuning yang telah dipelajarinya selama satu semester. Kedua, penilaian pada saat santri menyetorkan bacaannya, penilaiannya yaitu apabila santri telah lancar dalam membaca kitab dan dapat menerangkan dengan bahasa sendiri dengan baik, itu sudah termasuk baik nilainya.

Tabel 5. Daftar nilai santri kelas wustho pondok pesantren Al-Mahalli Tahun ajaran $2013 / 2014^{18}$ Mata pelajaran Taqrib

\begin{tabular}{clc}
\hline No & Nama & Nilai Semester 1 \\
\hline 1 & Intani Fathima A.A & 80 \\
2 & Evi Yuliani Wandasari & 80 \\
3 & Junaidah & 85 \\
4 & Agung Panji Kusuma & 75 \\
5 & Eka Rangga Mustafa & 85 \\
6 & Muh. Wahyu Nugroho & 85 \\
7 & Zusuf Nur Aziz & 85 \\
8 & Umi Salamah & 90 \\
9 & Siti Rofi'ah & 85 \\
10 & Siti Nur Amanah & 85 \\
11 & Choirul Anam & 85 \\
12 & Kholiq Amrullah & 75 \\
\hline & Jumlah & $\mathbf{9 9 5}$ \\
& Rata-rata & $\mathbf{8 2 , 8}$ \\
\hline
\end{tabular}

Dilihat dari perolehan hasil belajar pada tabel di atas, santri kelas Wustho bisa dikatakan berhasil dalam pembelajaran kitab kuning dengan menggunakan metode sorogan, karna nilai rata-rata yang diperoleh santri bagus.

hlm 249.

${ }^{18}$ Dokumentasi berupa daftar nilai mata pelajaran Taqrib, pada tanggal 15 April 2014 
Menurut Kemp dalam Mudhlofir di bukunya "teknologi intruksional" mengatakan bahwa ukuran efektif dapat diukur dari berapa jumlah santri yang berhasil mencapai tujuan belajar dalam waktu yang telah di tentukan. ${ }^{19}$ Dan pembelajaran kitab kuning tersebut termasuk dalam pembelajaran yang efektif karena telah memenuhi ketentuan yang ada pada bukunya Muh. User Usman yang berjudul "Menjadi Guru Profesuional" yang mengatakan bahwa dalam suatu pembelajaran dapat dikatakan efektif apabila dari segi pendidik dan dari segi peserta didik telah tercapai.

Di dalam buku Suharsimi Arikunto juga menyebutkan kriteria yang sering digunakan dalam penilaian, yaitu:

a. $80-100$ : sangat baik

b. $66-79$ : baik

c. $56-65$ : cukup baik

d. $40-55$ : kurang $^{20}$

Dengan hasil nilai semester satu, rata-rata nilai santri mata pelajaran kitab Ta'limul Muta'alim yang diajarkan dengan menggunakan metode bandongan adalah 84,8 dan rata-rata nilai santri mata pelajaran kitab Taqrib yang diajarkan dengan menggunakan metode sorogan adalah 82,8 , selisish antara nilai tersebut tidak jauh berbeda yaitu 2,00 dengan perbandingan rata-rata tersebut, maka pembelajaran metode bandongan dan sorogan prestasinya sangat baik, oleh karena itu kedua metode tersebut efektif diterapkan dalam pembelajaran kitab kuning di kelas Wustho Pondok Pesantren Al-Mahalli.

\section{Kelebihan dan Kekurangan}

Setiap ustadz pasti menginginkan proses belajar mengajar berjalan dengan lancar dan santri dapat menangkap apa yang ustadz berikan kepada mereka, akan tetapi segala sesuatu pasti ada kelebihan maupun kekurangan yang dapat mempengaruhinya. Berikut kelebihan dan kekurangan dalam menggunakan metode bandongan dan sorogan di Pondok Pesantren Al-Mahalli:

\section{Kelebihan dan kekurangan Metode Bandongan}

Pembelajaran kitab kuning dengan metode bandongan memiliki kelebihan tersendiri yaitu diantaranya: Pertama, mudah tempat. Maksudnya

${ }^{19}$ Mudhlofir, Teknologi Instruksional, (Bandung: Remaja Rosda Karya, 1990), hlm 145146.

${ }^{20}$ Suharsimi Arikunto, Dasar-dasar Evaluasi Pendidikan, (Jakarta: Bina Aksara, 1995), hlm 249 .

LITERASI, Volume V, No. 2 Desember 2014 
adalah pembelajaran kitab kuning dengan metode bandongan dapat dilakukan di manapun dengan jumlah santri yang banyak. Bahkan di tempat terbukapun pembelajaran tetap dapat dilaksanakan dengan kondusif. ${ }^{21}$ Kedua, efisien waktu. Maksudnya yaitu dengan 45 menit ustadz bisa menghatamkan satu bab yang terdapat dalam kitab Ta'limul Muta'alim dalam sekali atau dua kali pertemuan. Dengan demikian, pembelajaran kitab kuning dengan bandongan bisa lebih cepat dalam menghatamkan kitab.

Adapun kekurangan pembelajaran kitab kuning dengan menggunakan metode bandongan yaitu: pada saat ustadz membacakan makna dari kitab kadang santri merasa malas untuk menulis makna atau keterangan yang ustadz bacakan, jadi sering terjadi para santri tidak mencatat semua materi sehingga kitabnya masih banyak yang kosong.

\section{Kelebihan dan kekurangan Metode Sorogan}

Proses pembelajaran kitab kuning dengan menggunakan metode sorogan yaitu, satu persatu santri maju ke depan, membacakan kitabnya dengan begitu maka ustadz dapat mengetahui tingkat kelancaran santri dalam membaca kitab kuning, selain itu dengan metode sorogan juga dapat melatih mental santri, karena bagi seseorang yang tidak begitu percaya diri berhadapan dengan orang lain dengan metode sorogan yang diwajibkan di kelas wustho ini, maka siswa harus mengikuti peraturan yang ada di kelasnya, membangun sifat tanggung jawab santri, santri yang bertugas menyetorkan ia akan berusaha tampil yang terbaik, jadi sebelum menyetorkan santri harus memiliki persiapan terlebih dahulu.

Selain itu, metode sorogan memiliki kelebihan lain yaitu terjadinya komunikasi langsung antara santri dan ustadznya, sehingga santri menjadi terbiasa bertanya atau berbicara mengenai materi apabila mereka ada yang kurang paham menganai materi tersebut.

Dengan adanya komunikasi yang baik yaitu berupa tanya jawab antara ustadz dan santrinya sehingga menimbulkan hubungan yang positif pula antara mereka. Namun, keakraban di sini diikuti rasa hormat oleh santri terhadap ustadznya, sehingga wibawa ustadz sebagai pendidik tetap diakui oleh santrinya. Keakraban yang disertai rasa hormat santri kepada ustadz, maka akan menjadikan keseriusan santri dalam belajar kitab kuning.

Sedangkan kekurangan Metode Sorogan adalah dalam pembelajaran kitab kuning dengan menggunakan metode sorogan akan memerlukan waktu yang

${ }^{21}$ Hasil wawancara dengan ustadz pengampu mata pelajaran Ta'limul Muta'alim, pada tanggal 15 April 2014 
lama, karena yang menyetorkan satu persatu sehingga membutuhkan waktu yang lama, dan akan lama juga untuk mengkhatamkan kitabnya. Ada beberapa santri yang masih kesulitan membaca Arab pegon, sehingga akan menghambat santri lain untuk menyetorkan bacaan kitabnya.

Faktor Pendukung dan Faktor Penghambat dalam Pembelajaran Kitab Kuning

Di Pondok Pesantren Al-Mahalli terdapat beberapa faktor penghambat dan faktor pendukung, diantaranya $:^{22}$

\section{Faktor Penghambat}

Masalah waktu, dimaksudkan bahwa pelaksanaan proses belajar mengajar kitab kuning yang berlangsung selama ini pada sore hari, merupakan waktu yang melelahkan bagi para siswa, setelah dari pagi sampai siang terus menerus mengikuti pelajaran.

Mayoritas santri di Pondok Pesantren Al-Mahalli belum pernah mondok atau mengenal kitab kuning, sehingga membutuhkan waktu dan kesabaran dari ustadz untuk mengajarinya.

Dalam metode sorogan, sering kali terlihat beberapa santri tidak fokus dalam belajar, dikarenakan mereka tidak mendapat jatah giliran untuk maju kedepan. Dan dalam mengkhatamkan kitab memerlukan waktu yang lama, karena cara menyetornya harus satu persatu (metode sorogan).

\section{Faktor Pendukung}

Adanya ustadz/ustadzah yang berkualitas dan berpengalaman sesuai dengan bidangnya masing-masing, tersedianya sarana dan prasarana yang cukup memadai, dan peserta didik mayoritas tinggal di Pondok Pesantren sehingga secara otomatis terkondusif oleh lingkungannya tersebut.

Upaya yang dilakukan para ustadz untuk mengatasi kendala-kendala pada pembelajaran kitab kuning adalah: selain pada sore hari, madrasah diniyah juga dilaksanakan pada malam hari, sehingga pembelajaran kitab kuning akan optimal. Dan ustadz selalu berusaha menggali kreatifitas mereka agar metodemetode yang ustadz sampaikan kepada para satri bisa efektif.

\section{KESIMPULAN}

Setelah meneliti dan mendiskripsikan tentang efektifitas metode pembelajaran kitab kuning pada santri kelas Wustho Pondok Pesantren Al-

${ }^{22}$ Hasil wawancara dengan ustadz Ahmad Firdaus pengampu kitab Ta'lim dan ustadz pengampu kitab Taqrib, pada tanggal 15 April 2014

LITERASI, Volume V, No. 2 Desember 2014 
Mahalli Brajan Wonokroo Pleret Bantul Tahun ajaran 2013/2014, peneliti dapat mengambil kesimpulan bahwa:

1. Metode penyampaian kitab kuning di pondok pesantren pada umumnya adalah dengan menggunakan metode sorogan, bandongan dan wetonan. Metode ini merupakan metode yang hampir digunakan oleh seluruh pondok pesantren di Indonesia, termasuk pondok pesantren Al-Mahalli. Namun ada juga pondok pesantren yang pada perkembangan berikutnya mengalami perubahan sesuai dengan kemajuan atau perkembangan pondok pesantren.

2. Metode-metode pembelajaran kitab kuning tersebut, dari hasil wawancara dan observasi sudah dikatakan efektif dan berjalan dengan baik. Dalam menetukan keefektifannya, penulis mengacu pada buku Mudlofir yang berjudul "Teknologi Instruksional" dan Muh. User Usman yang berjudul "Menjadi Guru Profesional".

Selain dari hasil wawancara dan observasi, penulis mendapat data dari dokumentasi berupa nilai ujian santri selama satu semester. Nilai ujian atau evaluasi juga dapat menentukan keefektifitasan metode pembelajaran kitab kuning ini. Bentuk evaluasi dari pembelajaran kitab kuning dengan metode bandongan yang diterapkan oleh ustadz pada kelas Wustho ada dua macam, pertama, evaluasi setiap satu semester. Kedua, penilaian kitab, yaitu penilaian kitab santri setelah mengkhatamkan satu jilid kitab, yang dinilai yaitu penulisan terjemahan atau penulisan arab pegonnya, sesuai tidak dengan kaidah hukum nahwu shorofnya.

Evaluasi dari pembelajaran kitab kuning dengan metode sorogan yang diterapkan oleh ustadz pada kelas Wustho ada dua macam yaitu, pertama, evaluasi setiap satu semester. Kedua, penilaian pada saat santri menyetorkan bacaannya, penilaiannya yaitu apabila santri telah lancar dalam membaca kitab dan dapat menerangkan dengan bahasa sendiri dengan baik, itu sudah termasuk baik nilainya.

3. Ada beberapa faktor yang menjadi pendukung maupun penghambat mengenai keefektifitasan metode-metode pembelajaran kitab kuning di antaranya. Faktor penghambat meliputi: Masalah waktu, Mayoritas santri belum pernah mondok atau mengenal kitab kuning, sering kali terlihat beberapa santri tidak fokus dalam belajar, dikarenakan mereka sudah belajar dari pagi hari. Sedangkan faktor pendukungnya meliputi: Adanya ustadz/ustadzah yang berpengalaman sesuai dengan bidangnya masingmasing, tersedianya sarana dan prasarana yang cukup memadai, peserta didik mayoritas tinggal di Pondok Pesantren sehingga secara otomatis terkondusif oleh lingkungannya tersebut. 
Upaya yang dilakukan para ustadz untuk mengatasi kendala-kendala pada pembelajaran kitab kuning adalah: selain pada sore hari, madrasah diniyah juga dilaksanakan pada malam hari, sehingga pembelajaran kitab kuning akan optimal. Dan ustadz selalu berusaha menggali kreatifitas mereka agar metode-metode yang ustadz sampaikan kepada para satri bisa efektif.

\section{DAFTAR PUSTAKA}

Adi Kusuma. 1988. Kamus Lengkap Populer. Surabaya: Pustaa Tinta Mas.

Azhar Arsyad. 2003. Bahasa Arab Dan Metodepengajarannya. Yogyakarta: Pustaka Pelajar.

Azyurmadi Azra. 1999. Pendidikan Islam: Tradisi Dan Modernisasi Menuju Millenium Baru. Jakarta: Logos Wacana Ilmu.

Deliar Noer. 1985. Gerakan Modern Di Indonesia. Jakarta: Lp3s.

Imam Bawani. 1993. Tradisionalisme Dalam Pendidikan Islam. Surabaya: AlIkhlas.

M. Dawam Raharjo. 1985. Pergulatan Dunia Pesantren. Jaarta: P3m.

Marwan Saridjo Dkk. 1987. Sejarah Pondok Pesantren Di Indonesia. Jakarta: Dharma Bakti.

Mudlofir. 1990. Teknologi Instruksional. Bandung: Remaja Rosda Karya.

Muhammad Ali. 1987. Penelitian Kependidikan Prosedur Dan Strategi. Bandung: Angkasa.

Nana Sudjana. 1989. Cara Belajar Siswa Aktif Dalam Proses Belajar Mengajar. Bandung: Sinar Baru.

Robinson D. N Adjai. 1988. Asas-Asas Praktek Mengajar. Jakarta: Bharata.

S. Margono.2004. Metode Penelitian Pendidikan. Jakarta: Rineka Cipta.

S. Nasution. 1996. Metode Penelitian Naturalistik Kualitatif. Bandung: Tarsito. Sanjaya Wina. 2012. Strategi Pembelajaran Berorientasi Standar Proses Pendidikan. Jakarta: Kencana Predana Media Group.

Slameto. 2010. Belajar \& Faktor-Faktor Yang Mempengarubinya. Jakarta: Rineka Cipta. 
Sokah Umar Asasudin. 1982. Problematika Pengajaran Bahasa Arab Dan Inggris. Yogyakarta: Nur Cahaya.

Sugiyono. 2012. Metode Penelitian Pendekatan Kuantitatif Kualitatif Dan R $\odot D$. Bandung: Alfabeta.

Suharsimi Arikunto. 1995. Dasar-Dasar Evaluasi Pendidikan. Jakarta: Bina Aksara.

-------. 1998. Manajemen Penelitian. Jakarta: PT. Rineka Cipta.

--------. 2010. Prosedur Penelitian. Jakarta: PT. Rineka Cipta.

Sutrisno Hadi. 2000. Metodologi Research I. Yogyakarta: Andi Offset.

--------. 2004. Metodologi Research II. Yogyakarta: Andi Offset.

Syaifudin Azwar. 1999. Metode Penelitian. Yogyakarta: Pustaka Pelajar.

Tayar Yusuf. 1985. Ilmu Praktek Mengajar. Bandung: Alma 'Arif.

Usman Muh. User. 1995. Menjadi Guru Profesional. Bandung: Pt. Remaja Rosda Karya.

Winarno Surahmad. 1979. Metode Khusus Pelajaran Bahasa Arab. Surabaya: Usaha Nasional.

WJS Poerdarminto. 1982. Kamus Umum Babasa Indonesia. Jakarta: Balai Pustaka. Zamakhsyari Dhofier. Tradisi Pesantren. Jakarta: LP3ES.

Ensiklopedi Pendidikan Jilid 2. 1989. Jakarta: Cipta Adi Pustaka.

http:// muzayyinahns.blogspot.com. (diakses pada 21 Januari 2014 jam 20:23)

http://www.sarjanaku.com. (diakses pada 12 Februari 2014 jam 22:06)

Hidayat (1986) http://dansite.wordpress.com. (diakses pada 21 Desember 2013 jam 14:35)

http:/ /www.ut.ac.id. (diakses pada 10 April 2014 jam 19:17) 